\title{
UJI TOKSISITAS ORAL AKUT SINGLE DOSE FILTRAT BUAH LUWINGAN (Ficus hispida L.f.) PADA TIKUS (Rattus norvegicus Berkenhout, 1769) GALUR WISTAR
}

\author{
Laksmindra Fitria $^{1 *}$, Rosita Dwi Putri Suranto², Indira Diah Utami \\ ${ }^{1}$ Laboratorium Fisiologi Hewan Fakultas Biologi Universitas Gadjah Mada, \\ ${ }^{2}$ Program Sarjana Biologi Fakultas Biologi Universitas Gadjah Mada, \\ Jalan Teknika Selatan, Sekip Utara, Yogyakarta 55281. Telepon/Faksimili: (0274) 580839 \\ Email: *laksmindraf@ugm.ac.id
}

Doi: https://doi.org/10.31943/mangiferaedu.v4i1.39

Received: 7 Juli $2019 \quad$ Accepted: 18 Agustus 2019 Published: 23 Agustus 2019

Citasi: Fitria, L., Suranto, R.D.P., Utami, I.D., dan Puspitasari, S.A. (2019). Uji toksisitas oral akut single dose filtrat buah luwingan (Ficus hispida L.f.) pada tikus (Rattus norvegicus Berkenhout, 1769) Galur Wistar. Jurnal Mangifera Edu. 4(1): 1-18.

\section{ABSTRACT}

Genus Ficus is important plant for health benefits. Hairy fig (․․․ispida) trees grow abundantly in tropical regions and fruiting throughout the year. In West Asian countries, the fruit is commonly used as food and medicinal materials. However, in Indonesia, the fruit has not been utilized. First step in exploring the potential of natural resources for consumption is toxicity test to provide information about safety and adverse effects. This research was aimed to study acute oral toxicity of young and ripe hairy fig fruits using Wistarrats as model. Procedure followed OECD Guideline Test No.420 with modification in determining the dose/concentration. Pure filtrate (100\%) of young or ripe fruits were administered orally at volume $1 \mathrm{~mL} /$ individual on day-0 in fasting animals. Control received distilled water in the same way. Parameters observed including mortality, sublethal effects, behavior/activities, body weight, complete blood count, as well as evaluation of liver, heart, and renal functions. Results showed that values for all variables fluctuated during the experiment but eventually back into normal range. However, the number of lymphocytes elevated until the end of experiment (day-14) thus increased the total leukocytes count. Accordingly, we are preparing to conduct further toxicity tests to investigate this finding.

Keywords: acute oral toxicity, Ficus hispida, fruit filtrate, hairy fig, single dose toxicity

\section{ABSTRAK}

Tumbuhan anggota Genus Ficus memiliki banyak manfaat untuk kesehatan. Pohon luwingan $(F$. hispida) tumbuh subur di kawasan tropis dan berbuah sepanjang tahun. Di negara-negara Asia Barat, buahnya lazim dikonsumsi sebagai makanan dan obat-obatan. Di Indonesia, buah ini belum dimanfaatkan. Tahap pertama dalam rangka menggali potensi sumber daya hayati untuk dimanfaatkan sebagai bahan pangan maupun obat adalah uji toksisitas karena memberikan informasi keamanan dan efek samping yang ditimbulkan. Tujuan penelitian ini adalah untuk mempelajari toksisitas oral akut buah luwingan muda dan matang menggunakan model tikus Wistar. Prosedur uji mengikuti panduan OECD Guideline Test No. 420 dengan modifikasi. Filtrat murni (konsentrasi $100 \%$ ) buah muda atau matang dicekokkan sebanyak $1 \mathrm{~mL} /$ individu pada hari ke-0 kepada hewan uji yang telah dipuasakan sebelumnya. Kontrol berupa hewan uji yang dicekok air suling. Parameter pengamatan 
meliputi: ada tidaknya kematian, efek subletal, perilaku/aktivitas, berat badan, hitung darah lengkap, serta evaluasi fungsi hati, jantung dan ginjal. Hasil menunjukkan bahwa nilai untuk semua variabel mengalami fluktuasi selama percobaan namun pada akhirnya kembali ke dalam kisaran normal. Namun demikian, jumlah limfosit terus meningkat hingga akhir penelitian (hari ke-14) sehingga meningkatkan jumlah total leukosit. Oleh karena itu, kami tengah mempersiapkan uji toksisitas lanjutan guna mempelajari temuan ini.

Kata kunci: Toksisitas oral akut, Ficus hispida, Filtrat buah, Luwingan, Toksisitas dosis tunggal

\section{PENDAHULUAN}

Genus Ficus merupakan kelompok tumbuhan yang penting karena memiliki banyak manfaat baik untuk bahan pangan maupun obat-obatan (Lansky \& Paavileinen, 2011). Salah satu yang paling terkenal adalah $F$. carica atau yang biasa disebut ara/tin. Buahnya, baik yang masih muda maupun yang sudah matang, dapat dikonsumsi dalam kondisi segar atau setelah diolah/dimasak bahkan diawetkan (El-Shobaki, 2010; Joseph \& Raj, 2011; Saleem et al., 2013).

Ficus hispida berupa pohon berukuran sedang yang tumbuh liar di wilayah tropis dengan distribusi mulai dari Asia Barat ke Tenggara, Tiongkok, Australia, hingga Amerika. Spesies ini juga berlimpah di Indonesia, dikenal dengan nama luwingan. Tumbuhan ini mudah berkembang biak dan berbuah lebat sepanjang tahun (Gambar 1).

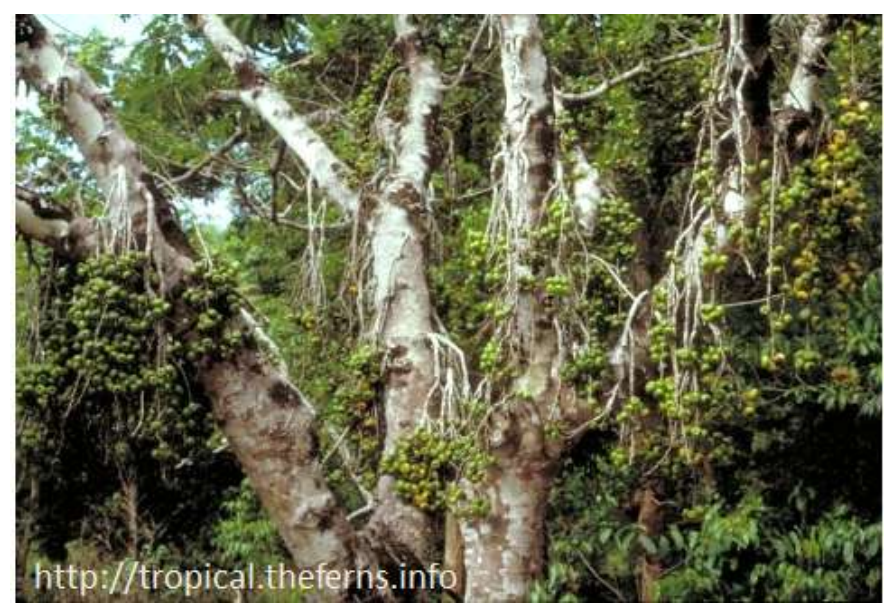

Gambar 1. Pohon luwingan (Ficus hispida L.f.)

Di Singapura, luwingan dibudidayakan sebagai tanaman perindang (Lee et al., 2011). Di India, buahnya dimanfaatkan sebagai obat tradisional dan bahan makanan (Ali \& Chaudhary, 2011). Di Nepal, buah, daun, akar, dan kulit batang F. hispida dimanfaatkan 
sebagai bahan obat dan pakan ternak karena kandungan gizinya (Kunwar \& Bussmann, 2006). Sementara itu, di Indonesia, luwingan belum banyak dimanfaatkan. Di Yogyakarta, pohon luwingan ditanam oleh pemerintah daerah pada proyek Taman Kehati di Desa Tepus, Kabupaten Gunung Kidul sebagai keanekaragaman tumbuhan lokal. Buahnya belum banyak dimanfaatkan oleh masyarakat (Kehati, 2009).

Beberapa penelitian ilmiah telah menggali manfaat luwingan sebagai bahan obat, namun masih terbatas pada daun, batang, kulit pohon, dan akar (Mandal \& Kumar, 2002; Lansky \& Paavileinen, 2011; Murti et al., 2011). Informasi mengenai pemanfaatan buahnya masih terbatas (Shahreen et al., 2012). Buah luwingan dapat dimakan namun kadang-kadang menyebabkan pusing. Buah yang dicampur dedak sebagai pakan itik/ayam dapat meningkatkan produksi telur dan juga mengobati penyakit kulit (Kehati, 2009).

Penelitian ini bertujuan untuk mempelajari toksisitas oral akut filtrat buah luwingan muda dan matang menggunakan model tikus (Rattus norvegicus). Uji toksisitas merupakan langkah pertama dalam rangka eksplorasi potensi sumber daya hayati untuk dimanfaatkan sebagai bahan pangan maupun obat karena memberikan informasi keamanan dan efek samping yang ditimbulkan, sekaligus menjadi dasar penentuan dosis/konsentrasi dalam pembuataan sediaan (OECD, 2001).

Uji toksisitas oral akut oleh Odo et al. (2016) membuktikan bahwa $F$. carica aman dikonsumsi. Sebaliknya, Bello et al. (2015) melaporkan bahwa tikus percobaan yang diberi F. sycomorus menunjukkan tanda-tanda ketoksikan hingga terjadi kematian. Sementara itu, penelitian oleh Ntchapda et al. (2014) menggunakan $F$. glumosa menyebutkan bahwa ada kejadian diare dan perubahan perilaku/aktivitas namun hanya sementara. Tidak ada kematian, tidak menurunkan nafsu makan, dan pertumbuhan normal. Berdasarkan hal ini dapat disimpulkan bahwa tidak semua spesies Ficus aman dikonsumsi. Oleh karena itu penelitian ini penting guna mendapatkan informasi keamanan mengkonsumsi $F$. hispida.

\section{METODOLOGI PENELITIAN}

Prosedur yang dilakukan dalam penelitian ini telah disetujui oleh Komisi Kelaikan Etik Hewan Coba Laboratorium Penelitian dan Pengujian Terpadu (LPPT) UGM dengan diterbitkannya Sertifikat Kelaikan Etik Nomor 304/KEC-LPPT/VII/2015 tanggal 27 Juli 2015.

Bahan Uji. Bahan uji berupa buah luwingan (Ficus hispida L.f.) segar dipetik langsung pada musim kemarau (Juni-Oktober) dari pohon yang tumbuh di Hutan Biologi 
Fakultas Biologi UGM. Identifikasi spesies dilakukan berdasarkan Backer \& van den Brink (1965).

Buah muda berwarna hijau, sementara buah matang berwarna kuning merata (Gambar 2). Buah dicuci bersih dengan air mengalir, diparut lembut, lalu diperas sehingga diperoleh filtrat konsentrasi $100 \%$. Filtrat dibuat segar dan disaring terlebih dahulu sebelum diberikan kepada hewan uji. Pencekokan dilakukan 1x (single dose) pada awal percobaan (H-0) dengan volume $1 \mathrm{~mL} / \mathrm{individu}$ setelah hewan uji dipuasakan makan selama 6 jam (Fitria dkk., 2015).

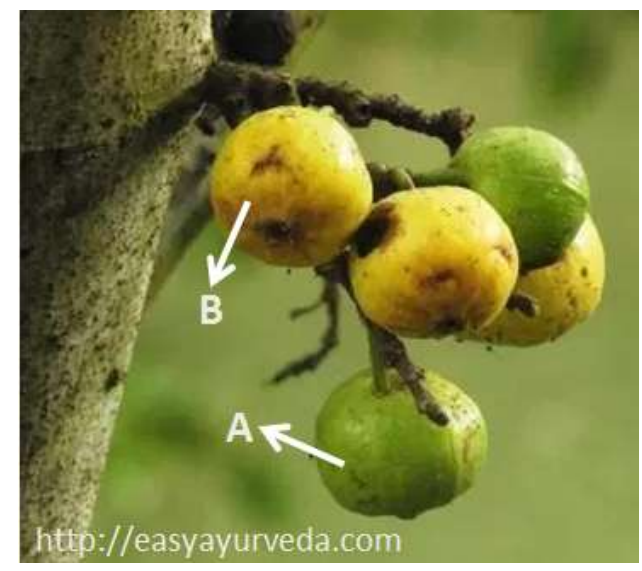

Gambar 2. Buah luwingan (Ficus hispida L.f.)

Keterangan: $\mathrm{A}=$ buah muda (hijau), $\mathrm{B}=$ buah matang (kuning)

Hewan Uji. Hewan uji adalah 9 ekor tikus (Rattus norvegicus Berkenhout, 1769) Galur Wistar yang diperoleh dari Fakultas Farmasi UGM. Hewan berjenis kelamin betina, berumur 8 minggu dan belum pernah dikawinkan. Kisaran berat badan adalah 75-123 gram atau dengan rerata 100,33 $\pm 17,73$ gram. Hewan uji dikelompokkan menjadi 3 kandang, masing-masing untuk perlakuan filtrat buah muda, filtrat buah matang, dan kontrol.Kontrol adalah hewan uji yang dicekok air suling sebanyak $1 \mathrm{~mL} /$ individu (plasebo).

Percobaan ini dilakukan di Animal Room Laboratorium Fisiologi Hewan, Fakultas Biologi UGM dengan suhu ruang 25-26 ${ }^{\circ} \mathrm{C}$, kelembapan 60-70 \%, fotoperiode $12 \mathrm{G}: 12 \mathrm{~T}$ dengan pencahayaan artifisial. Hewan dipelihara dalam kandang komunal standar untuk tikus laboratorium. Alas tidur (bedding) berupa sekam padi yang sudah disterilisasi menggunakan autoklaf. Ransum berupa pelet standar yang diberikan ad libitum dengan pertimbangan tikus laboratorium makan sebanyak 10-15\% dari berat badannya.Air minum reverse osmosis (RO) diperoleh dari depo air minum kemasan IQ Fresh Yogyakarta diberikan ad libitum. Sanitasi dilakukan seminggu sekali. Sebelum percobaan dimulai, 
hewan diaklimasi hingga menunjukkan perilaku normal/alamiah, tidak stres terhadap lingkungan baru dan habituasi dengan peneliti.

Uji Toksisitas. Prosedur uji toksisitas oral akut dalam penelitian ini mengacu pada OECD Test Guideline No.420 dengan modifikasi (Limit Test). Bahan uji dalam bentuk filtrat digunakan secara keseluruhan, tanpa penambahan bahan pelarut, dan tanpa melalui proses pengolahan sehingga konsentrasi awal ditentukan sebagai $100 \%$. Apabila selama percobaan tidak ada kematian, efek subletal, maupun perilaku/aktivitas, maka bahan uji dinyatakan aman/lolos uji pertama sehingga dapat dilanjutkan dengan uji toksisitas berikutnya.Apabila terjadi tanda-tanda ketoksikan seperti tersebut di atas, maka konsentrasi diturunkan (OECD, 2001).

Pengambilan data. Perilaku/aktivitas hewan uji secara kualitatif diamati setiap hari meliputi perilaku/aktivitas individual dan sosial, termasuk apabila muncul tanda-tanda ketoksikan sebagai manifestasi klinis yang mengarah ke kondisi subletal dan adanya kematian. Titik sampling pengamatan kondisi fisiologis yang meliputi berat badan, hitung darah lengkap, dan evaluasi fungsi organ dilakukan pada hari ke-0; 4; 7; 10; dan 14. Nilai yang diperoleh pada hari ke-0 digunakan sebagai baseline atau kisaran normal dalam penelitian ini.

Sampel darah untuk hitung darah lengkap (profil hematologi) dan evaluasi fungsi organ dikoleksi dari sinus orbitalis sebanyak $1 \mathrm{~mL}$, ditampung dalam microtube yang telah ditambah EDTA sebagai zat antikoagulan. Profil hematologi diperiksa menggunakan hematology analyzer Sysmex ${ }^{\circledR}$ XP-100 dengan variabel: jumlah eritrosit (x106/ $\left.\mu \mathrm{L}\right)$, nilai hematokrit $(\%)$, kadar hemoglobin $(\mathrm{g} / \mathrm{dL})$, jumlah total leukosit $\left(\mathrm{x} 10^{3} / \mu \mathrm{L}\right)$, jumlah neutrofil $\left(\mathrm{x} 10^{3} / \mu \mathrm{L}\right)$, jumlah limfosit $\left(\mathrm{x} 10^{3} / \mu \mathrm{L}\right)$, dan jumlah trombosit $\left(\mathrm{x} 10^{5} / \mu \mathrm{L}\right)$.

Sampel darah selanjutnya disentrifus menggunakan minicentrifuge Corning ${ }^{\circledR} \operatorname{Costar}^{\circledR}$ dengan kecepatan 4500 rpm selama 10 menit hingga diperoleh plasma untuk pengujian fungsi organ menggunakan clinical chemistry analyzer Microlab $300^{\circledR}$. Variabel uji fungsi hati berupa aktivitas ALT (U/L), uji fungsi jantung berupa aktivitas AST (U/L), dan uji fungsi ginjal berupa kadar kreatinin (g/dL).

Anestesi dan eutanasi. Sebelum pengambilan darah, hewan uji dianestesi dengan cara injeksi intramuscular ketamin dosis $50 \mathrm{mg} / \mathrm{kg}$ BB. Pada hari terakhir percobaan, hewan uji dieutanasi dengan cara injeksi intramuscular ketamin dosis $100 \mathrm{mg} / \mathrm{kg}$ BB dilanjutkan eksanguinasi. Bangkai dan semua limbah penelitian disimpan dalam freezer $-30{ }^{\circ} \mathrm{C}$ untuk selanjutnya dilakukan insinerasi (pengabuan). 
Analisis data. Data ditabulasi dalam MS-Excel ${ }^{\circledR}$ untuk dilakukan rekapitulasi dan uji deskriptif yang meliputi nilai rerata dan simpangan. Data hari ke-0 disortir untuk menentukan baseline atau nilai kisaran normal populasi hewan uji dalam penelitian ini yang digunakan sebagai pembanding. Data juga dianalisis secara statistik berdasarkan ANOVA two-factor $(\mathrm{a}=0,05)$ menggunakan Analysis Toolpak MS-Excel ${ }^{\circledR}$.

\section{HASIL DAN PEMBAHASAN}

\section{Uji toksisitas}

Studi pustaka menyatakan bahwa masyarakat di beberapa negara telah mengkonsumsi buah luwingan muda maupun matang sebagai bahan makanan sehari-hari. Oleh karena itu buah ini hampir dipastikan tidak memiliki efek letal yang bersifat akut. Berdasarkan alasan tersebut maka uji toksisitas yang dilakukan adalah Limit Test (OECD, 2001) dengan konsentrasi tertinggi, yaitu $100 \%$. Hal ini karena bahan uji dalam bentuk filtrat digunakan secara keseluruhan, tanpa penambahan bahan pelarut, dan tanpa melalui proses pengolahan seperti halnya infusa, ekstraksi, dan sebagainya.

Uji toksisitas yang dilakukan oleh banyak peneliti selama ini hanya memberikan informasi mengenai dosis/konsentrasi yang menyebabkan $50 \%$ populasi hewan uji mati (LD50 atau LC50).Padahal tidak semua zat memiliki efek letal. Oleh karena itu OECD (Organisation for Economic Co-operation and Development) merancang panduan atau guideline uji toksisitas yang tidak hanya bertujuan menentukan LD50 atau LC50 saja, namun juga mempelajari ada tidaknya efek subletal yang ditunjukkan dengan perubahan fisiologis yang berdampak pada aktivitas/perilaku sehari-hari. Selain itu, uji toksisitas versi OECD juga dapat diaplikasikan untuk keperluan penentuan dosis/konsentrasi dalam uji praklinik (OECD, 2002 ${ }^{\mathrm{a}}$.

Peneliti memilih metode toksisitas menurut OECD karena telah diakui secara internasional. Kelebihan lain uji toksisitas versi OECD dibandingkan uji toksisitas konvensional yang banyak diacu peneliti selama ini adalah mengenai jumlah hewan, jenis kelamin, jumlah kelompok, penentuan dosis, dan parameter yang diamati. Penggunaan hewan dibatasi hanya 3-5 individu per kelompok, jenis kelamin hewan uji tidak harus jantan, bahkan disarankan betina, jumlah kelompok diminimalisir sesuai prosedur yang dipilih, penentuan dosis bahan uji dipertimbangkan berdasarkan kegunaan zat yang diuji, dan parameter pengamatan tidak semata-mata mengenai kematian hewan uji namun juga manifestasi klinis yang menggambarkan kondisi fisiologis hewan uji yang hidup. Ada 3 metode uji toksisitas oral akut yang dapat dipilih, yaitu Guideline Test No.420, 423, atau 
$425\left(\mathrm{OECD}, 2002^{\mathrm{b}}\right)$.Dahulu OECD juga memiliki prosedur uji toksisitas konvensional (Guideline Test No.401) namun telah resmi dihapus/tidak berlaku lagi sejak 17 Desember 2002.

\section{Mortalitas, efek subletal, dan perilaku/aktivitas}

Sampai dengan hari terakhir percobaan (hari ke-14) tidak ada kematian (mortalitas) maupun tanda-tanda ketoksikan sebagai manifestasi klinis yang menunjukkan efek subletal pada kelompok yang diberi filtrat buah luwingan muda ataupun matang. Menurut OECD (2002), tanda-tanda ketoksikan yang bersifat subletal dapat diamati dari perubahan morfologis, dalam hal ini adalah rambut teraba kasar dan tidak rapi, mata, moncong, dan ekor tampak kotor. Hal ini karena tikus yang sakit tidak melakukan grooming dengan baik. Efek subletal juga dapat diamati dari perubahan fisiologis seperti penurunan nafsu makan, diare, gangguan napas, dan tubuh yang lemah. Kondisi ini berdampak pada penurunan berat badan dan perubahan perilaku/aktivitas, di mana tikus menjadi pasif, lebih suka berdiam menyendiri, dan menolak bergaul dengan sesamanya. Pada percobaan ini, semua hewan uji menunjukkan perilaku/aktivitas individual maupun sosial yang normal seperti halnya pada kontrol.

Hasil yang sama dilaporkan pada uji toksisitas oral akut $F$. benghalensis (Chandra et al., 2013), F. pseudopalma (Santiago et al., 2013), dan F. septica (Jangad \& Licardo, 2015) bahwa tidak ada kematian dan perubahan perilaku/aktivitas harian pada hewan uji selama percobaan sehingga dapat disimpulkan bahwa bahan uji aman dikonsumsi sebagai makanan ataupun kandidat obat baru.

\section{Berat badan}

Pemberian filtrat buah luwingan muda atau matang tidak mengurangi nafsu makan hewan uji, ditandai dengan perilaku/aktivitas sehari-hari yang normal dan pertumbuhan yang wajar sebagaimana pada kontrol. Laju pertumbuhan dapat diketahui dari pertambahan berat badan yang diukur secara rutin pada titik sampling (Gambar 3). 

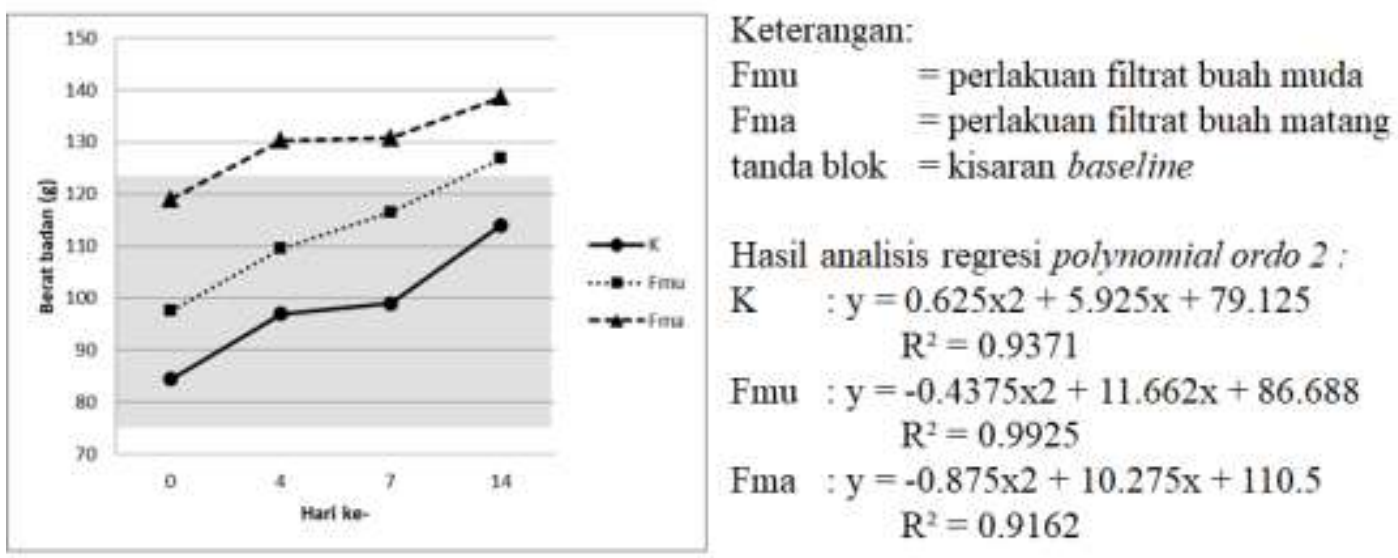

Gambar 3. Berat badan hewan pada uji toksisitas oral akut single dose filtrat buah luwingan muda dan matang menggunakan model tikus Wistar

Kisaran berat badan awal (baseline) adalah 75-123 gram dan terus bertambah seiring waktu. Hasil uji statistik menyatakan bahwa pertambahan berat badan bersifat signifikan seiring waktu $(P<0,05)$ namun bukan merupakan efek filtrat buah luwingan karena laju pertumbuhan kelompok perlakuan memiliki pola yang relatif sama dengan kontrol. Hal ini diketahui dari nilai $\mathrm{R}^{2}$ yang diperoleh dari analisis regresi polynomial ordo 2 (Gambar 3 ).

Hasil uji toksisitas oral akut $F$. platyphylla (Chindo et al., 2012) dan $F$. religiosa (Elavarasi et al., 2018) juga menyatakan bahwa tidak terjadi penurunan berat badan pada hewan uji bahkan terjadi peningkatan. Hal ini mengindikasikan bahwa konsumsi Ficus tidak menurunkan nafsu makan maupun mengganggu sistem pencernaan. Hasil sebaliknya pada uji toksisitas oral akut $F$. racemosa justru menurunkan nafsu makan yang berdampak pada penurunan berat badan (Jaykaran et al., 2008). Hasil ini menunjukkan bahwa tidak semua Ficus aman untuk dikonsumsi.

Untuk mempelajari secara lebih seksama efek filtrat buah luwingan muda maupun matang terhadap kondisi fisiologis hewan uji, maka dilakukan pemeriksaan darah. Menurut Jothy et al. (2011), darah merupakan komponen yang sangat sensitif terhadap senyawa yang masuk ke dalam tubuh. Oleh karena itu darah menjadi parameter yang penting untuk menentukan status fisiologis dan patologis pada manusia maupun hewan pada uji toksisitas bahan kimia. Pemeriksaan darah sebagai parameter dalam uji toksisitas ini meliputi uji hematologi rutin di mana salah satu parameternya adalah hitung darah lengkap atau complete blood count (CBC) serta uji kimia darah untuk evaluasi fungsi hati, jantung, dan ginjal (Derelanko, 2008).

\section{Profil hematologis (hitung darah lengkap)}


Hasil pemeriksaan hematologi rutin atau hitung darah lengkap disajikan pada Gambar 4:
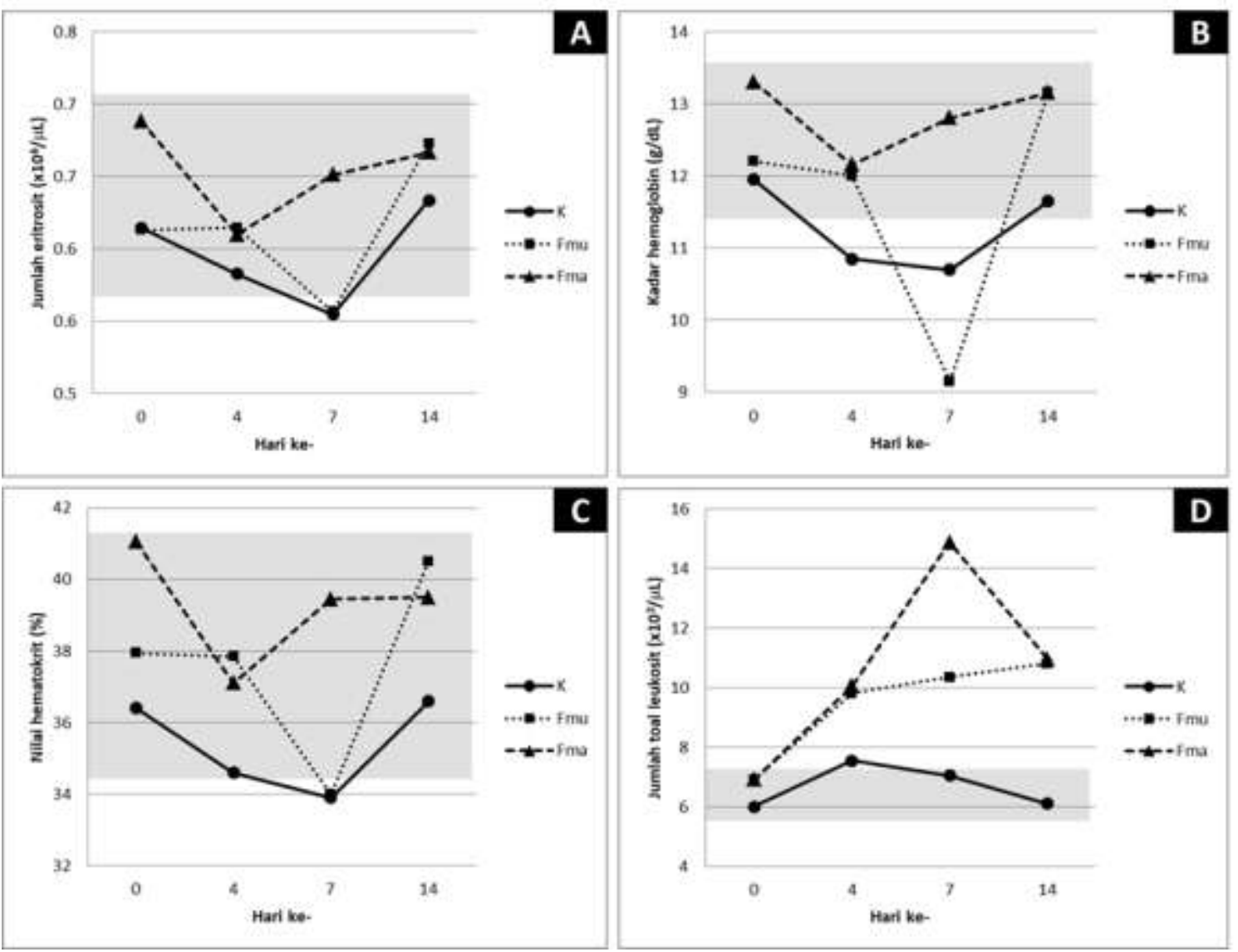

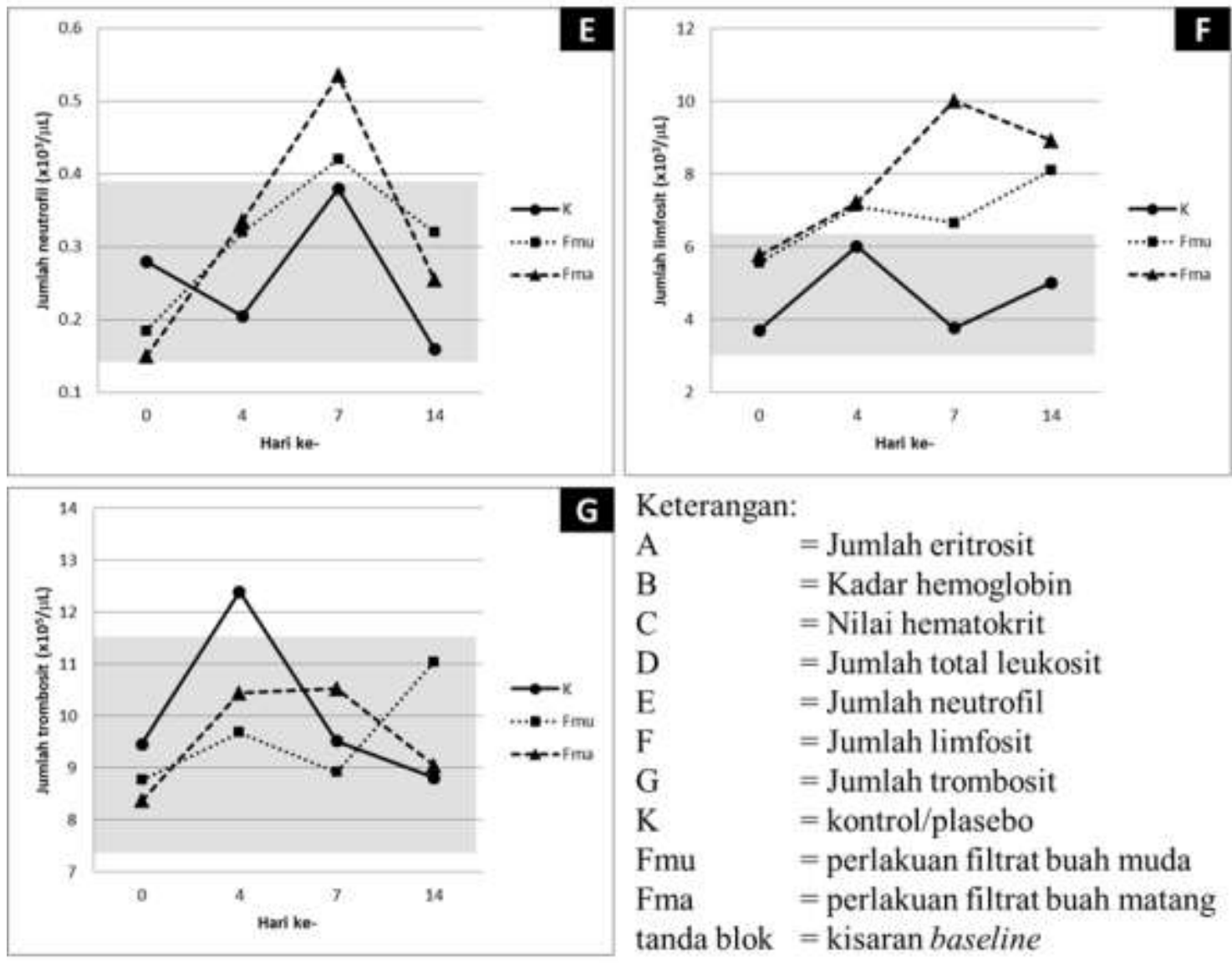

Gambar 4. Profil hematologis pada uji toksisitas oral akut single dose filtrat buah luwingan muda dan matang menggunakan model tikus Wistar

Profil hematologi adalah salah satu parameter pokok dalam penelitian praklinik.Masuknya senyawa asing ke dalam tubuh dapat mengganggu kondisi fisiologis, dan efeknya dapat diketahui dari perubahan profil hematologi (Iheidioha et al., 2012).Eritrosit berkaitan dengan fungsi penyediaan oksigen untuk kebutuhan energi dalam rangka metabolism.Leukosit berhubungan erat dengan sistem pertahanan tubuh atau imunitas.Leukosit jenis neutrofil bertanggung jawab terhadap respons imun bawaan, sedangkan limfosit memegang peranan penting dalam respons imun adaptif. Trombosit merupakan komponen utama dalam koagulasi darah dalam rangka hemostasis (Fitria \& Mulyati, 2014).

Profil eritrosit yang diamati dalam penelitian ini terdiri atas jumlah eritrosit, kadar hemoglobin, dan nilai hematokrit(Gambar 4A-C).Jumlah eritrosit menunjukkan nilai kuantitatif eritrosit per volume darah, sedangkan hematokrit merupakan nilai kualitatif eritrosit dalam satuan persen. Keduanya digunakan untuk mendeteksi anemia yang disebabkan rendahnya jumlah eritrosit. Anemia ini berbeda dari anemia akibat rendahnya kadar hemoglobin (Weiss \& Wardrop, 2010). Nilai untuk ketiga variabel tersebut fluktuatif, bahkan berada di luar kisaran normal (baseline eritrosit $=5,69-7,06 \times 10^{6} / \mu \mathrm{L}$, hemoglobin= 
11,4-13,6 g/dL, hematokrit=34,5-41,7\%) pada hari k-7. Namun demikian, hasil uji statistik menyatakan bahwa tidak ada perbedaan signifikan antarkelompok dan antarwaktu $(P>0,05)$. Hal ini berarti filtrat buah luwingan tidak memiliki efek negatif seperti menyebabkan anemia.

Profil leukosit yang diamati dalam penelitian ini meliputi jumlah leukosit total, jumlah neutrofil, dan jumlah limfosit (Gambar 4D-F). Nilai baseline untuk ketiga variabel tersebut berturut-turut adalah 5,7-7,2; 0,9-3,3; dan 3,0-6,3 x10\%3/ L. Jumlah leukosit total meningkat secara signifikan $(P<0,05)$ hingga hari ke-14, disebabkan oleh bertambahnya jumlah limfosit.Peningkatan jumlah limfosit yang diikuti fluktuasi hematokrit mengindikasikan bahwa buah luwingan memiliki potensi imunomodulasi. Imunomodulator adalah substansi yang mampu memodifikasi aktivitas sistem imun, baik dengan cara meningkatkan ataupun menekan respons imun melalui mekanisme tertentu (Yadav et al., 2015). Imunomodulator dapat berupa imunostimulasi atau imunosupresi (Fitria \& Marwayana, 2015).Masuknya antigen, dalam hal ini zat yang terkandung dalam filtrat buah luwingan menjadi stimulator yang memicu proliferasi dan aktivasi limfosit sehingga jumlahnya bertambah banyak.Namun demikian masih perlu penelitian lebih lanjut untuk memastikannya.

Jumlah trombosit pada semua kelompok mengalami fluktuasi (Gambar 4G), bahkan pada kontrol hingga di atas kisaran normal pada hari ke-4 (baseline $\left.=7,23-11,68 \times 10^{5} / \mu \mathrm{L}\right)$. Hasil uji statistik menyatakan bahwa peningkatan ini tidak signifikan $(P>0,05)$, yang berarti pemberian buah luwingan tidak mengganggu aktivitas trombosit dalam rangka hemostasis.

Sebagai perbandingan, hasil uji toksisitas oral akut oleh Bafor et al. (2009) menggunakan $F$. exasperata, Odo et al. (2016) menggunakan $F$. carica, dan Estella et al. (2018) menggunakan $F$. thonningii juga melaporkan bahwa perlakuan dengan ketiga spesies Ficus tersebut tidak mengganggu profil hematologis hewan uji.

\section{Evaluasi fungsi organ}

Hasil evaluasi fungsi organ yang meliputi hati, jantung, dan ginjal disajikan pada Gambar 5: 

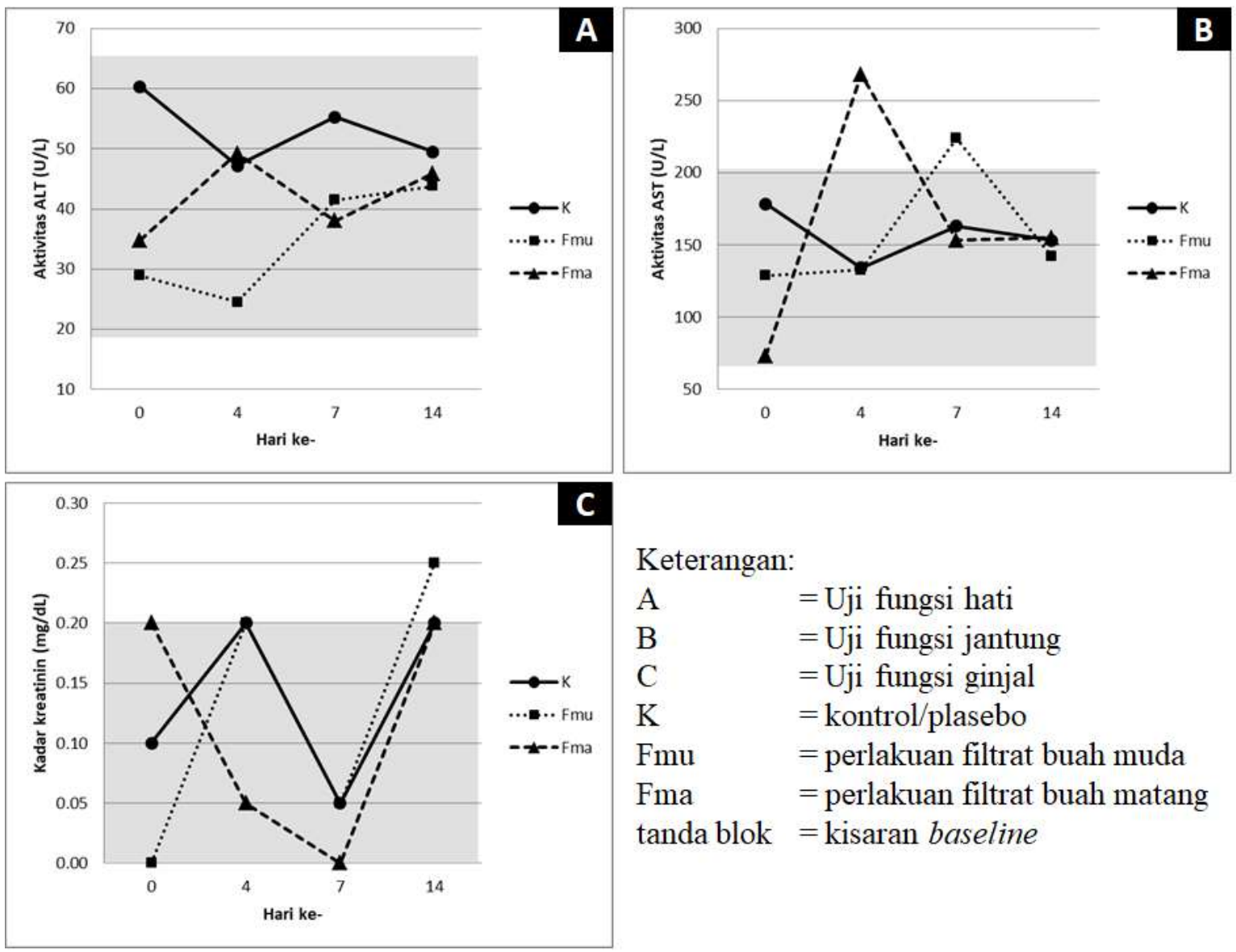

Keterangan:
A $\quad=$ Uji fungsi hati
B $\quad=$ Uji fungsi jantung
$\mathrm{C} \quad=$ Uji fungsi ginjal
$\mathrm{K}=$ kontrol/plasebo
Fmu $=$ perlakuan filtrat buah muda
Fma $\quad=$ perlakuan filtrat buah matang
tanda blok $=$ kisaran baseline

\section{Gambar 5. Hasil evaluasi fungsi organ pada uji toksisitas oral akut single dose filtrat buah luwingan muda dan matang menggunakan model tikus Wistar}

Alanin aminotransferase (ALT) atau yang dahulu disebut sebagai serum glutamic pyruvic transaminase (SGPT) adalah enzim intrasel yang dapat dijadikan indikator fungsi hati. Peningkatan aktivitas ALT menunjukkan penurunan fungsi hati, yaitu: detoksifikasi, glikogenesis, serta sekresi berbagai enzim dan protein plasma. Senyawa toksik merusak selsel hati (hepatosit) menyebabkan se-sel tersebut pecah atau lisis sehingga ALT masuk ke sirkulasi darah dan dapat diukur (Basten, 2010, Evans, 2009; Pagana and Pagana, 2014).

Gambar 5A menunjukkan bahwa aktivitas ALT pada semua kelompok berada di dalam kisaran normal (baseline = 19,7-65,3 U/L) sejak awal hingga akhir percobaan, yang berarti fluktuasi nilai yang terjadi merupakan dinamika fisiologis normal. Hal ini didukung oleh hasil uji statistik yang menyatakan bahwa tidak ada perbedaan signifikan antarwaktu dan antarkelompok $(P>0,05)$.

Seperti halnya AST, aspartat aminotransferase (AST) atau yang dahulu disebut sebagai serum glutamic oxaloacetic transaminase (SGOT) juga merupakan enzim intrasel.Enzim ini diproduksi di sel-sel hati, jantung, otot, dan beberapa organ lainnya, 
sehingga peningkatan aktivitas AST dapat digunakan sebagai indikator adanya gangguan fungsi jantung (Basten, 2010, Evans, 2009; Pagana and Pagana, 2014).

Gambar 5B menunjukkan bahwa terjadi peningkatan aktivitas AST pada kelompok yang diberi perlakuan filtrat buah luwingan hingga di atas kisaran normal (baseline $=72,2$ 207,5 U/L). Meskipun hasil uji statistik menyatakan bahwa peningkatan ini signifikan $(P<0,05)$, namun aktivitas AST kembali ke dalam kisaran normal mendekati kontrol.

Kreatinin merupakan senyawa yang dihasilkan dari kontraksi otot. Secara spontan, senyawa ini akan terbentuk pada saat otot berkontraksi (Bhutta et al., 2013). Menurut Basten (2010), kreatinin adalah variabel utama untuk evaluasi fungsi ginjal karena secara konsisten diekskresikan melalui ginjal untuk dikeluarkan dari dalam tubuh sebagai urin. Peningkatan kadar kreatinin dalam sirkulasi darah mengindikasikan adanya gangguan fungsi filtrasi oleh glomerulus dan/atau fungsi absorbsi oleh tubulus proksimal (Bhutta et al., 2013).

Gambar 5C menunjukkan bahwa kadar kreatinin pada semua kelompok mengalami fluktuasi namun masih berada dalam kisaran normal (baseline $=0,0-0,2 \mathrm{mg} / \mathrm{dL}$ ), kecuali pada kelompok yang diberi perlakuan filtrat buah luwingan muda, peningkatan ini hingga melebihi kisaran normal. Meskipun hasil uji statistik menyatakan bahwa peningkatan ini tidak signifikan $(P>0,05)$ namun perlu uji lanjutan untuk mengetahui apakah nilai ini terus naik atau kembali ke kisaran normal.

Berdasarkan hasil evaluasi fungsi hati, jantung, dan ginjal, dapat disimpulkan bahwa senyawa yang terkandung di dalam filtrat buah luwingan muda maupun matang tidak mengganggu fungsi ketiga organ tersebut. Hasil yang sama juga ditunjukkan pada beberapa uji toksisitas oral akut tumbuhan Ficus lainnya, antara lain: F. virens (Jayashree, et al., 2012), F. deltoidea (Farsi, et al., 2013), dan F. pumila (Larbie et al., 2016).

\section{Pembahasan Komprehensif}

Pemberian per oral filtrat buah luwingan muda maupun matang dengan konsentrasi $100 \%$ secara single dose pada tikus Wistar betina tidak menyebabkan kematian maupun perubahan perilaku/aktivitas normal sampai dengan hari ke-14. Terjadi peningkatan berat badan yang menunjukkan bahwa filtrat buah luwingan tidak menurunkan nafsu makan atau mengganggu proses pencernaan. Hasil pemeriksaan profil hematologis menunjukkan bahwa filtrat buah luwingan tidak memberikan efek negatif terhadap jumlah, morfologis, maupun aktivitas eritrosit dan trombosit. Namun demikian, filtrat buah luwingan meningkatkan jumlah limfosit secara signifikan $(P<0,05)$ sehingga penelitian lebih lanjut diperlukan untuk mengetahui apakah peningkatan ini merupakan respons imun aktif atau immunosurveillance 
normal. Ditinjau dari hasil pemeriksaan parameter sebelumnya, kami menduga bahwa peningkatan jumlah limfosit ini bukan aktivasi respons imun spesifik namun bentuk imunomodulasi karena tidak disertai dengan tanda-tanda sakit pada hewan uji. Hasil evaluasi fungsi hati, jantung, dan ginjal menunjukkan bahwa filtrat buah luwingan tidak menurunkan kinerja ketiga organ tersebut. Kandungan senyawa bioaktif dalam buah luwingan tidak merusak sel-sel hati dan jantung, serta tidak mengganggu fungsi filtrasi dan absorbsi ginjal.

Berdasarkan hasil yang diperoleh, maka dapat dinyatakan bahwa pemberian filtrat buah luwingan muda maupun matang dengan konsentrasi $100 \%$ secara single dose pada tikus Wistar sebagai model untuk penelitian praklinik bersifat relatif aman atau no observed adverse effect level pada konsentrasi $100 \%($ NOAEL $=100 \%)$. Oleh karena uji toksisitas ini bersifat single dose yang berarti bahan uji hanya diberikan satu kali saja, maka perlu dilanjutkan dengan uji toksisitas tahap berikutnya dengan memberikan bahan uji secara berulang (repeated dose) dan dalam jangka waktu yang lebih panjang (OECD, 2008).

\section{SIMPULAN}

Berdasarkan hasil yang diperoleh dalam uji toksisitas oral akut single dose ini dapat disimpulkan bahwa filtrat buah luwingan muda maupun matang relatif aman dikonsumsi dalam jangka waktu terbatas oleh tikus Wistar sebagai model praklinik. Namun demikian, jumlah limfosit terus meningkat sehingga berpotensi mempengaruhi kerja sistem imun. Oleh karena itu, perlu dilakukan uji toksisitas lanjutan guna mempelajari temuan ini.

Selain itu, karena buah luwingan telah lolos uji toksisitas tahap awal, maka akan dilakukan pula studi fitokimia untuk mempelajari kandungan senyawa bioaktif buah luwingan muda maupun matang dalam rangka menggali potensinya sebagai bahan pangan fungsional (nutrasetika) ataupun bahan obat (terapeutika) di masa depan.

\section{UCAPAN TERIMAKASIH}

Penelitian ini dapat terlaksana dengan adanya skema Hibah Penelitian dengan Dana BOPTN Fakultas Biologi UGM Tahun Anggaran 2015. Kami juga mengucapkan terima kasih kepada Septy Azizah Puspitasari dan Paradhita Zulfa Nadia yang ikut bergabung dalam tim dan akan melanjutkan penelitian ini. 


\section{DAFTAR PUSTAKA}

Ali, M. and Chaudhary, N. (2011). Ficus hispida Linn: A review of its pharmacognostic and ethnomedical properties. Pharmacognosy Review, 5, 96-102.

Backer, C.A. \& van den Brink, R.C.B. (1965). Flora of Java (Spermatophytes only). Volume 2, Angiospermae, Families 111-160. N.V.P. Noordhoff. Groningen, The Netherlands.

Basten, G. (2010). Introduction to clinical biochemistry: Interpreting blood results. Denmark: Ventus Publishing ApS. Frederiksberg.

Bafor, E. and Igbinuwen, O. (2009). Acute toxicity studies of the leaf extract of Ficus exasperata on haematological parameters, body weight and body temperature. Journal of Ethnopharmacology, 123(2), 302-307. doi: 10.1016/j.jep.2009.03.001.

Bello, O.M., Ojediran, O.J., Dada, A.O., Olatunya, A.M., and Awakan, O.J. (2015).In vivo toxicity studies and phytochemical screening of stem bark of Ficus sycomorus Linn (Moraceae). IOSR Journal of Environmental Science, Toxicology and Food Technology, 9(3), 72-74.

Bhutta, RA., Syed, N.A., Ahmad, A., and Khan, S. (2013). Lab Tests for SGPT (ALT, Alanine amino-transferase, Serum Glutamic-Pyruvic Transaminase), SGOT (Aspartate amino-transferase, AST, Glutamic oxaloacetic Transaminase), Blood Urea Nitrogen (BUN, Urea Nitrogen), and Creatinine (Serum Creatinine).http://www.labpedia.net.

Chandra, P., Sachan, N., Chaudhary, A., Yadav, M., Kishore, K., and Ghosh, A.K. (2013). bengalensis L. (Family: Moraceae) on scopolamine-induced memory impairment in experimental animals. Indian Journal of Drugs, 1(1), 6-16.

Chindo, B.A., Anuka, J.A., amd Gamaniel, K.S. (2012). Toxicity screenings of Ficus platyphylla stem bark in rats. Pharmacologia, 3(10), 499-505. DOI: 10..5567/ pharmacologia.2012.499.505.

Derelanko, M.J. (2008). The Toxicologist's Pocket Handbook. $2^{\text {nd }}$ ed. Informa Healthcare USA, Inc. New York.

Elavarasi, S., Horne, I.A., Kanimozhi, P., and Nevika, E. (2018). Acute toxicity evaluation of Ficus religiosa bark extract on albino rats. International Journal of Creative Research Thoughts, 6(2), 11-20.

El-Shobaki, F.A., El-Bahay, A.M., Esmail, R.S.A., El-Megeid, A.A.A., and Esmail, N.S. (2010). Effects of figs fruit (Ficus carica L.) and its leaves on hyperglycemia in alloxan diabetic rats. World Journal of Dairy \& Food Sciences, 5(1), 47-57.

Estella, T.F., Jessica, P.K., Joseph, N., Nono, N.B., Evrard, N., Omgba, T.Y., Grace, M., Bathelemy, N., Kaba, N., and Fokunang, C. (2018). Evaluation of the toxicity of secondary metabolites in aqueous extracts of Ficus thonningii Blume in Wistar rats.American Journal of Ethnomedicine, 5(2), 13 DOI: 10.21767/2348-9502.100013. 
Evans, G.O. (2009). (ed). Animal clinical chemistry: A practical guide for toxicologists and biomedical researchers. $2^{\text {nd }}$ ed. CRC Press, Taylor \& Francis Group. Boca Raton, Florida, USA.

Farsi, E., Shafaei, A., Hor, S.Y., Ahamed, M.B.K., Yam, M.F., Asmawi, M.Z., and Ismail, Z. (2013). Genotoxicity and acute and subchronic toxicity studies of a standardized methanolic extract of Ficus deltoidea leaves. Clinics, 68(6), 865-875.

Fitria, L. dan Mulyati. (2014). Profil hematologi tikus (Rattus norvegicus Berkenhout, 1769) galur Wistar jantan dan betina umur 4, 6, dan 8 minggu. Biogenesis, 2(2), 94-100 DOI: https://doi.org/10.24252/bio.v2i2.473.

Fitria, L. dan Marwayana, O.N. (2015). Potensi propolis sebagai imunomodulator pada tikus (Rattus norvegicus Berkenhout, 1769) galur Wistar yang diinduksi PenisilinG.Biogenesis, 3(2), 124-131 DOI: https://doi.org/10.24252/bio.v3i2.937.

Fitria, L., Suranto, R.D.P., dan Utami, I.D. (2015). Uji Potensi Buah Luwingan (Ficus hispida L.f.) sebagai Penurun Kadar Kolesterol Darah dengan Hewan Model Tikus (Rattus norvegicus Berkenhout, 1769) Galur Wistar Hiperlipidemia.Laporan Penelitian.Hibah Penelitian Dana BOPTN Tahun Anggaran 2015. Yogyakarta: Fakultas Biologi Universitas Gadjah Mada.

Ihedioha, J.I., Ugwuja, J.I., Noel-Uneke, O.A., Udeani, I.J., and Daniel-Igwe, G. (2012). Reference values for the haematology profile of conventional grade outbred albino mice (Mus musculus) in Nsukka, Eastern Nigeria. Animal Research International, 9(2), 16011612.

Jangad, A.M.A and Licardo, A.D.M.B. (2015). Acute and chronic toxicity studies of Lagnob (Ficus septica Burm. F. 1768) fruit extract on albino rats (Rattus norvegicus). Thesis.Pharmacy Department/School of Health Care Professions University of San Carlos-Josef Baumgartner, Filipina.http://www.herdin.ph/index.php/partners?view =research\&cid=69231\#physiLoc.

Jayashree, P., Shridhar, N.B., Vijaykumar, M., Suhasini, K., Jayakumar, and Satyanarayana, M.I. (2012). Toxicological studies of Ficus virens in Wistar Albino rats. International Research Journal of Pharmacy, 3(12), 84-87.

Jaykaran, Bhardwaj, P., Kantharia, N, Yadav, P., and Panwar, A. (2008). Acute toxicity study of an aqueous extract of Ficus racemosa Linn.bark in albino mice. The Internet Journal of Toxicolog, .6(1), 1-6.

Joseph, B. and Raj, S.J. (2011). Pharmacognostic and phytochemical properties of Ficus carica Linn-An overview.International Journal of PharmTech Research, 3(1), 8-12.

Jothy, S.L., Zakaria, Z., Chen, Y., Lau, Y.L., Latha, L.Y., and Sasidharan, S. (2011). Acute oral toxicity of methanolic seed extract of Cassia fistula in mice. Molecules, 16(6), 52685282. 
Kehati. (2009). Jenis-jenis tanaman lokal dan endemik di wilayah Provinsi Daerah Istimewa Yogyakarta. Pembangunan Taman Keanekaragaman Hayati Provinsi DIY Tahun Anggaran 2009. Lampiran 1.

Kunwar, R.M. and Bussmann, R.W. (2006). Ficus (Fig) species in Nepal: A review of diversity and indigenous uses. Lyonia 11(1): 85-97.

Lansky, E.P. and Paavilainen, H.M. (2011). Figs: The genus Ficus: Traditional herbal medicines for modern times. Florida: CRC Press. Taylor and Francis Group, LLC..

Larbie, C., Owusu, K.P., Torkornoo, D., and Asibey, O. (2016). Acute and sub-chronic toxicity of aqueous ethanolic extract of Ficus pumila leaves in rats. European Journal of Biomedical and Pharmaceutical Sciences, 3(8), 22-27.

Lee, S.H., Ng, A.B.C., Ong, K.H., O’Dempsey, T, and Tan, H.T.W. (2011).The status and distribution of Ficus hispida L.f. (Moraceae) in Singapore. Nature in Singapore, 6, 8590 .

Mandal, S.C. and Kumar, C.K.A. (2002). Studies on anti-diarrhoeal activity of Ficus hispida leaf extract in rats. Fitoterapia, 73, 663-667.

Murti, K, Lambole, V., and Panchal, M. (2011). Effect of Ficus hispida L. on normal and dexamethasone suppressed wound healing. Brazilian Journal of Pharmaceutical Sciences, 47(4), 855-860.

Ntchapda, F., Abakar, D., Kom, B., Nana, P., Hamadjida, A., and Dimo, T. Acute and subchronic oral toxicity assessment of the aqueous extract leaves of Ficus glumosa Del. (Moraceae) in rodents. Journal of Intercultural Ethnopharmacology, 3(4), 206-213. doi: 10.5455/jice.20140913021547.

Odo, G.E., Agwu, J.E., Newze, N., Nwadinigwa, A., Onyeke, C.C., Nzekwe, U., Ajuziogu, G.C., Osayi, E. I., and Ikegbunam, C. (2016). Toxicity and effects of fig (Ficus carica) leaf aqueous extract on haematology and some biochemical indices of wistar albino rats (Rattus norvegicus).Journal of Medicinal Plants Research, 10(22), 298-305.

OECD. (2001). OECD Test No. 420: Acute Oral Toxicity-Fixed Dose Procedure. OECD Guidelines for the Testing of Chemicals.Section 4. OECD Publishing. Paris. Document per December 17, 2001. PDF https://doi.org/10.1787/9789264070943-en.

OECD. (2002 ${ }^{\mathrm{a}}$. OECD Test No. 420: Acute Oral Toxicity-Fixed Dose Procedure. OECD Guidelines for the Testing of Chemicals., Section 4: Health Effects264070943-en. Document per February 09, 2002. Update https://www.oecd-ilibrary.org/ environment/test-no-420-acute-oral-toxicity-fixed-dose-procedure 9789OECD.

OECD. $\left(2002^{\mathrm{b}}\right)$. Guidance Document on Acute Oral Toxicity Testing. OECD Series on Testing and Assessment No. 24. OECD Publishing, Paris. Document per May 10, 2002. https://doi.org/10.1787/9789264078413-en. 
OECD. (2008). Test No. 407: Repeated Dose 28-day Oral Toxicity Study in Rodents.OECD Guidelines for the Testing of Chemicals.Section 4. OECD Publishing, Paris, https://doi.org/10.1787/9789264070684-en.

Pagana, K.D. and Pagana, T.J. (2014). Mosby's manual of diagnostic and laboratory tests. $5^{\text {th }}$ ed. Mosby, an imprint of Elsevier Inc. Missouri, USA.

Salem, M.Z.M., Salem, A.Z.M., Camacho, L.M., and Ali, H.M. (2013). Antimicrobial activities and phytochemical composition of extracts of Ficus species: An overview. African Journal of Microbiology Research, 7(33), 4207-4219.

Santiago, L.A., Valerio, V.L.M., and Yolo, R.T. (2013). Acute oral toxicity study of the crude ethanolic leaf extract of Ficus pseudopalma Blanco (Moraceae) in Sprague Dawley Rats.International Journal of Research and Development in Pharmacy and Life Sciences, 2(6), 674-679.

Shahreen, S., Banik, J., Hafiz, A., Rahman, S., Zaman, A.T., Shoyeb, M.A., Chowdhury M.H., and Rahmatullah, M. (2012). Antihyperglycemic activities of leaves of three edible fruit plants (Averrhoa carambola, Ficus hispida, and Syzygium samarangense) of Bangladesh. AfricanJournal Traditional Complement Alternative Medica, 9(2), 287-291.

Weiss, D.J. and Wardrop, K.J. (2010). Schalm's veterinary hematology. $6 \mathrm{t}^{\mathrm{h}} \mathrm{ed}$. WileyBlackwell Publishing Ltd. Ames, Iowa, USA.

Yadav, S.K., Nagarathna, P.K.M., and Yadav, C.K. (2015). Evaluation of immunomodulatory activity of Dalbergia latifolia on Swiss albino mice. IOSR Journal of Pharmacy and Biological Sciences, 10(3), 58-64. 